\title{
Mediation for medical malpractice actions: an efficient approach to the law and veterinary care
}

\author{
Valeria Quartarone, Maria Russo, Alessandra Fazio, Annamaria Passantino* \\ Department of Veterinary Public Health, Faculty of Veterinary Medicine, University of Messina, Polo Universitario Annunziata, \\ Messina, Italy; *Corresponding author: passanna@unime.it
}

Received 24 May 2011, revised 27 May 2011, accepted 20 June 2011.

\begin{abstract}
Veterinarians today face an increased risk for malpractice claims in view of increased client awareness of the benefits of the human-animal bond and advances in preventive and specialized veterinary medicine. An important problem with medical malpractice litigation is the manner in which malpractice claims are resolved. In several countries, thousands of claims have been successfully resolved via Alternative Dispute Resolution processes such as mediation, conciliation and arbitration. In medical mediation, health care providers, patients/animal owners, families, clergy and attorneys participate directly in an informal, usually voluntary, dispute resolution process that can lead to for unique and promising approaches to resolving conflicts. Recently in Italy framework legislation addressing mediation has been introduced and it is also used to resolve medical malpractice disputes. Given that in Italy medical mediation is formally a new concept and is still evolving, an examination is made. The importance of "mediation" for veterinarians' civil liability will be evaluated, underlining how it could become an important instrument in speeding up the resolution of court actions concerning medical malpractice.
\end{abstract}

Keywords: Mediation; Alternative Dispute Resolution; Veterinarian; Malpractice; Legislation

\section{INTRODUCTION}

Medical malpractice occurs when a patient suffers harm, injury, loss or damage to function by a physician, veterinarian, dentist, pharmacist, therapist or any other medical care provider who fails to competently perform his or her medical duties by providing improper, un- skilled, or negligent treatment to a patient.

Medical negligence can include a failure to diagnose, improper treatment, and failure to warn a patient of known risks. In cases of vicarious liability or direct corporate negligence, claims may also be brought against hospitals, clinics, managed care organizations or medical corporations for the mistakes of their employees.

Medical malpractice law is highly regulated by a complex body of rules, which vary from country to country. These rules include how soon a medical malpractice claim must be filed; whether the patient must submit the claim to a malpractice review panel before filing the claim in court; whether notice of the malpractice claim must be given to the doctor before filing; what qualifications are required to be deemed an expert medical witness for the purposes of testifying; and what statutory caps exist on the amount of compensation that can be awarded.

Professional negligence is the predominant theory of liability concerning allegations of medical malpractice. A person who alleges negligent medical malpractice must prove all four elements of the tort of negligence: 1) a physician/veterinarian-patient/animal owner relationship existed, so a duty of care was owed by the physician/veterinarian; 2) the physician/veterinarian violated the applicable standard of care, giving proof of negligence, generally demonstrated by expert testimony or obvious errors;3) the physician's negligence caused the injury; and iv) the person/animal suffered a compensable injury, meaning that the injury led to specific damages. The burden of proving these elements is on the plaintiff; the healthcare provider is the defendant.

Lawsuits within the healthcare system reduce the quality of patient care and medical malpractice litigations can be extremely expensive and unsatisfactory for every party involved, so it is important to find ways of saving money and time.

Access to justice, in its widest sense of the effective resolution of disputes whether through court-based liti- 
gation or alternative dispute resolution (ADR) [1] processes, is an essential aspect of ensuring the realisation of the fundamental rights recognised and given protection by the $\mathrm{EU}[2,3]$.

The modern civil justice system offers various approaches and options for dispute resolution thus promoting access to justice.

Citizens should be empowered to find a satisfactory solution to their problem which includes the option of a court-based litigation but as part of a wider menu of choices.

While the courts will always maintain a central place in the civil justice system, it is increasingly recognised throughout the world that, in many instances, there may be alternative and perhaps more appropriate methods of resolving civil disputes in a manner which may be more cost and time efficient for all parties.

Merely because a dispute is defined as justifiable does not necessarily mean that the courts are the only option to seek redress.

In Italy, the Law aims to facilitate access to dispute resolution and to promote the amicable settlement of disputes by encouraging the use of mediation and by ensuring a functioning interaction between mediation and judicial proceedings. Mediation is legally enforceable in the United States, European Union and Asia. Individuals or business can utilize Veterinary Mediation as an out-of-court settlement process to avoid lawyer and court costs.

In law suits relating to claims for medical liability damages, both in human and in veterinary medicine, the medico-legal technical consultancy has a key role in determining whether the event the veterinarian is charged with (death, worsening of the disease) is actually due to professional misconduct or to other factors which will exonerate the veterinarian from professional responsibility $[4,5]$.

The foregoing brief remarks show how and why legal proceedings relating to the investigation of medical liability, of whatever kind, take a very long time to reach a conclusion, because of their complexity and the way in which this particular responsibility has to be established and verified in practice. Moreover, in recent years lawsuits against veterinarians have increased exponentially, with a consequent overloading of the judicial system. So Italian Legislative Decree (LD) No. 28/2010, which introduces a new procedural method to be activated in the field of actions for damages resulting from medical liability, is to be welcomed as it should help speed up the settlement of such legal disputes [6]. It establishes the institution of mediation aimed at reconciliation, which is an obligatory preliminary stage for those who wish to take legal action to assert their right to compensatory damages against a physician/veterinarian considered responsible for those damages through their professional conduct.

In this paper the main objectives and principles of mediation and conciliation and their role in a modern civil justice system will be examined.

The importance of the institution of "mediation" for veterinarians' civil liability will be evaluated, underlining how it could become an important instrument in speeding up the resolution of court actions concerning medical malpractice.

\section{DISTINGUISHING BETWEEN MEDIATION AND CONCILIATION}

The inconsistent use of both mediation and conciliation terminology and principles potentially affects consumers, researchers, policy makers, courts and tribunals, all of whom need consistent and accurate information on mediation and conciliation. As a result, it is likely that many disputes that could effectively be resolved through these methods end up in the courts and tribunals.

Mediation and conciliation, terms often used interchangeably, are two distinct concepts.

The term "mediation" is derived from the Latin word "mediare" which means to be in the middle.

Mediation is an extension of direct negotiation between the parties, using a neutral third party (i.e., a mediator) to facilitate the negotiation process [7]. As a facilitator, the mediator has no authority to impose a solution on the parties nor are the results of the process binding on the disputing parties.

Conciliation is a more formal process than mediation and it could generally involve the engagement of legal representatives, thus making it a more expensive process than mediation. There is, however, the added advantage that should no amicable solution be reached, the conciliator has the duty to attempt to persuade the differing parties to accept his own solution to the dispute.

When provision for mediation is made in legislative form, it should be defined as a facilitative consensual and confidential process, in which parties to the dispute select a neutral and independent third party to assist them in reaching a mutually acceptable negotiated agreement.

When provision for conciliation is made in legislative form, it should be defined as an advisory, consensual and confidential process, in which parties to the dispute select a neutral and independent third party to assist them in reaching a mutually acceptable negotiated agreement.

It is evident that the fundamental difference between mediation and conciliation is the degree of involvement by the neutral and independent third party in the respective processes. 
Another important distinguishing feature between mediation and conciliation can be found in a comparison between a rights-based approached to resolving a dispute and an interested-based approach to resolving a dispute.

Interest-based dispute resolution processes expand the discussion beyond the parties' legal rights to look at the underlying interests of the parties; they also address parties' emotions and seek creative solutions to the resolution of the dispute. The focus of these processes is on clarifying the parties' real motivations or underlying interests in the dispute with the aim of reaching a mutually acceptable compromise which meets the real interests of both parties. It is generally accepted that mediation is a purely interest-based dispute resolution process. In conciliation, there can be a greater focus on the legal rights of the parties as opposed to their underlying interests.

On the basis of these considerations, it is evident that there is a fundamental procedural difference between the role of the conciliator and that of a mediator.

The conciliator is a more active intervener, and may have an advisory role on the content and the outcome of a dispute. A conciliator may make suggestions, give expert advice and use intervention techniques that not only actively influence the likely terms of an agreement, but also encourage all parties to settle. A mediator on the other hand generally helps the parties to communicate with each other so that they can identify, clarify and explore the issues in dispute before they consider their options to reach a mutually acceptable negotiated agreement.

Mediation and conciliation have a statutory definition.

Several jurisdictions have already legislated for mediation and provide statutory definitions for the process. For example, Article 1 of the Austrian Civil Law Mediation Act 2003 defines mediation as "an activity voluntarily entered into by the Parties, whereby a professionally trained neutral facilitator (Mediator) using recognised methods systematically encourages communication between the Parties, with the aim of enabling the Parties to themselves reach a resolution of their dispute" [8].

Similarly, Section 5 of the Commercial Mediation Act 2005 in Nova Scotia defines mediation as "a collaborative process in which parties agree to request a third party, referred to as a mediator, to assist them in their attempt to try to reach a settlement of their commercial dispute, but a mediator does not have any authority to impose a solution to the dispute on the parties" [9].

In the United States, mediation is defined under Section 2(1) the Uniform Mediation Act 2004 as "a process in which a mediator facilitates communication and negotiation between parties to assist them in reaching a voluntary agreement regarding their dispute”. The Uniform
Mediation Act was drafted by the National Conference of Commissioners of Uniform State Laws and approved by it and recommended for enactment in all the states, August 10-17, 2001 and amended August 1-7, $2003^{1}$.

The 2002 UNCITRAL Model Law on International Commercial Conciliation defines conciliation as "a process, whether referred to by the expression conciliation, mediation or an expression of similar import, whereby parties request a third person or persons (the conciliator) to assist them in their attempt to reach an amicable settlement of their dispute arising out of or relating to a contractual or other legal relationship. The conciliator does not have the authority to impose upon the parties a solution to the dispute"2.

The Centre for Effective Dispute Resolution in the United Kingdom defines conciliation as "a process where the neutral takes a relatively activist role, putting forward terms of settlement or an opinion on the case" ${ }^{\text {"3 }}$.

In Italy the LD No. 28/2010, specifically, defines "mediation" as "the activity carried out by an impartial third party aimed at assisting two or more subjects, both in the search for an amicable agreement for the settlement of a dispute and in the formulation of a proposal for the solution of the same". The term "conciliation" means, however, "the settlement of the dispute after mediation has been carried out", that is, a solution achieved through mediation, while the term "Organ of conciliation" indicates the "public or private body where the mediation process may take place”.

It is important to fully understand what the legislators were aiming to achieve with the introduction of this obligatory stage before moving on to the usual legal procedures so as to make an analysis of possible practical consequences for the health professions. Analysis of the principles behind the enabling act whose direction the Italian Government had to follow when emanating the related law shows clearly that the legislator's intention was to create an alternative system which would be more agile and speedy than ordinary procedures. Indeed it is now mandatory for specific civil and commercial proceedings and is available in all cases for disputes concerning available rights (that is to say, those rights for which the holder may act in terms of availability, of waiver of transfer, thus property rights in general). This method of dispute settlement is indubitably of great significance because, even though it is obligatory, it is not a substitute for the ordinary systems of justice. In other words, although this procedural stage is obligatory, it must in no way "preclude access to justice". Indeed,

${ }^{1}$ For more details, see the following website:

http://www.law.upenn.edu/bll/archives/ulc/mediat/2003finaldraft.htm

${ }^{2}$ Available at www.uncitral.org.

${ }^{3}$ See www.cedr.co.uk 
even when the professional bodies that are in charge of it have a requirement of independence (for example, judges) and offer conciliation/mediation services in the long-term, they do not have the faculty to pronounce any decisional sentence (which arbitration bodies may do). The only pronouncement made by "mediators" which can produce juridical effects between the parties is the "Statement of Agreement" which, once it has been examined by the presiding judge in whose district the professional body is and has been found to be both formally and substantially in order, may become an actual sentence by means of a decree of homologation. It is of interest here to see what bodies may aspire to become an "Organ of conciliation". Article 16 of the Legislative Decree specifies that only those public and private bodies which can guarantee efficiency and reliability will be permitted to intervene in mediation; inclusion in a special register is also necessary.

It should also be noted that the Councils of professional associations may, after receiving authorisation from the Ministry of Justice, establish special bodies from their own staff and on their own premises, to deal with matters relating to their specific spheres of expertise. Another important innovation, which can also have a useful deterrent function, is the provision of special rules concerning the payment of court costs. In contrast to the rule which has the loser of the case pay the costs, the regulations examined here contemplate the possibility that, in those cases where the sentence pronounced in the ordinary proceedings exactly corresponds to the agreement set out in the conciliation phase the judge may decide not to recoup the costs incurred by the winner if the latter rejected the agreement at the earlier stage and, moreover, sentence him/her to repay the loser's costs and a further sum as a contribution to court expenses. The possibility of being sentenced to pay damages remains, if the judge decides that the party has undertaken a 'reckless' lawsuit, as well as a subsequent sentence to pay the fees of experts who may have assisted the Organs of conciliation in lawsuits where specific technical knowledge is required.

\section{CONCLUDING REMARKS}

In the light of the innovations in civil proceedings relating to medical liability disputes, the institution of mediation should be welcomed as, in future, it could become a valuable instrument for settlement of disputes. By taking a constructive approach, mediation allows the parties involved to focus on the real interests at stake and will, if time scales are evaluated appropriately, enable favourable agreements for all parties to be reached without long delays.

The advantages of mediation over litigation are its lower costs, more confidential proceedings, and the degree of control enjoyed by the disputing parties over the process and outcome. In contrast, the legal system is public, adversarial, lasts longer, clients and lawyers keep track of who has treated whom the worst, and creates an atmosphere of conflict and offers no emotional resolution.

In resolving allegations of medical negligence, patients/owners tend to favour mediation because it provides a forum in which they can express their concerns and may lead to a recognition of the problem.

In conclusion, mediation can be effective in medical malpractice cases in which the patient and the healthcare professional wish to preserve their relationship or in which poor communication has led to the dispute.

\section{ACKNOWLEDGEMENTS}

The authors thank Caroline Keir for her kind correction of the English language of the manuscript.

\section{REFERENCES}

[1] Meschievitz, C. (1991) Mediation and medical malpractice: Problems with definition and implementation. Law and Contemporary Problems, 54, 195-202. doi:10.2307/1191859

[2] EC (1950) Convention for the protection of human rights and fundamental freedoms as amended by protocol No. 11 and No. 14, Rome.

[3] EC (2000) Charter of Fundamental Rights of the European Union. Official Journal of the European Communities, 18.12.2000, C364, 1-22.

[4] Panichi, M., Di Pietro, C., Passantino, A. (2003) Errori professionali e responsabilità del medico veterinario. Rassegna di Diritto e Legislazione e Medicina Legale Veterinaria, 2, 35-38.

[5] Passantino, A. (2002) La colpa professionale in medicina veterinaria. Rivista Italiana di Medicina Legale, 4, 1061-1077.

[6] Anon (2010) Decreto Legislativo 4 marzo 2010, n. 28. Gazzetta Ufficiale della Repubblica Italiana 5 marzo 53.

[7] Fuller, L. (1971) Mediation: Its forms and functions. Southern California Review of Law, 44, 305-339.

[8] Anon (2003) Bundesgesetzblatt für die Republik Österreich, pp. 123-133.

http://www.ris.bka.gv.at/Dokumente/BgblPdf/2003_29_1 /2003_29_1.pdf.

[9] Anon (2005) Commercial Mediaction Act, S.N.S. 2005, 36. 